\title{
Effect of Humic Acids on Lead Accumulation in Chicken Organs and Muscles
}

\author{
Z. ZRALÝ, B. PÍSAŘÍKOVÁ, M. TRČKOVÁ, M. NAVRÁTILOVÁ \\ Veterinary Research Institute, Brno, Czech Republic \\ Received November 12, 2007 \\ Accepted April 14, 2008
}

\begin{abstract}
Zralý Z., B. Písaříková, M. Trčková, M. Navrátilová: Effect of Humic Acids on Lead Accumulation in Chicken Organs and Muscles. Acta Vet. Brno 2007, 77: 439-445.

The purpose of the present study was to investigate the effect of feeding humic acid (HA) to pullets treated for 10 days on its concentrations in the organs and muscles. Forty pullets allocated to 4 groups with ten birds in each were used in the experiment. Control group (K) was fed the basic diet without supplementation. The second group (HA) was fed the basic diet with HA at the dose of $500 \mathrm{mg} /$ chicken/day. Experimental group $1(\mathrm{~Pb})$ was fed basic diet containing lead acetate at the dose of $3.54 \mathrm{mg}(1.42 \mathrm{mg} \mathrm{Pb})$ per pullet/day and the second experimental group $(\mathrm{Pb}+\mathrm{HA})$ was moreover fed $500 \mathrm{mg} \mathrm{HA} /$ day. The lead content was determined in the samples of liver, kidney, bone and muscle tissue. Very low lead concentrations detected in the liver, kidneys and muscles of control group constituted the background, which reflected the current status of nutrition. The lead concentrations in the tissues were $4 \%, 12.6 \%$ and $10 \%$ of the highest admissible amounts $(0.5$ and $0.1 \mathrm{mg} \mathrm{Pb} / \mathrm{kg})$, respectively. In the experimental group $(\mathrm{Pb})$, significantly increased lead concentrations were detected in liver, kidneys, bones $(P<0.001)$ and muscles $(P<0.05)$. The highest accumulation was found in bones $(2.711 \pm 0.59 \mathrm{mg} / \mathrm{kg})$. Concurrent administration of HA and lead acetate (HA $+\mathrm{Pb}$ group) caused a significant decrease in the $\mathrm{Pb}$ content, i.e. by $30 \%, 43.8 \%, 53.8 \%$ and 50.6\% in liver, kidneys, muscles and bones, respectively, in contrast to experimental group $\mathrm{Pb}$. The values of selected biochemical indicators ranged in reference value limits, except the significant decrease of copper concentration in experimental groups.
\end{abstract}

Lead acetate, liver, kidney, muscle tissue, bone, humic substances

Ecotoxicological issues associated with the food chain protection and guarantee of the food safety assurance require a steadily increased attention concentrated on the investigation of effective substances that might decrease the accumulation of xenobiotics in the organisms of food animals or decrease their toxicity. In particular after the dioxin contamination episode in Belgium in 1999, an increased attention was paid to the investigation and the use of non-nutrient adsorptive substances in the diet with the aim to decrease accumulation of the pollutants in organs and tissues of animals and to support their excretion (Cabanero et al. 2005).

Humic acids (HA) are organic compounds naturally present in water and soil. They form three-dimensional structure molecules, containing aromatic nuclei with oxygen and nitrogen heterocycles. In the side chains, bound to an aromatic nucleus, hydroxyl, carbonyl, carboxyl, amine and sulfhydryl functional groups are present (MacCarthy 2001). Due to different HA structures, the content of functional groups and various qualities (colloidal, spectral, electrochemical and ion exchange) their considerable adsorption capacity is assumed (Klocking 1994; Alvarez Puebla et al. 2005). The mean molecular mass ranges between 20000 and 150000 .

In the past, humic substances were studied above all owing to their positive effect on the animal organism. Krugov and Maykova (1988) documented an increased efficiency in broiler chickens and in other farm animals, a supporting effect on the reproduction, offspring vitality and meat quality. After feeding sodium humate to calves, Griban et

Address for correspondence:

MVDr. Zdeněk Zralý, CSc.

Veterinary Research Institute

Hudcova 70

62132 Brno, Czech Republic
Phone: +420 533331612

Fax: +420541211229

E-mail: zraly@vri.cz

http://www.vri.cz

http://www.vfu.cz/acta-vet/actavet.htm 
al. (1988) found an increased body weight gain and decreased mortality; after feeding the same product to dairy cows, decreased occurrence of mastitis and milk somatic cell counts were detected. Antiflogistic, antitoxic, antibacterial and antiviral effects were documented for humic acids; these can be used for therapy and prevention (Lenk and Benda 1989; Klocking 1994). Due to the fact that no toxic, allergic, mutagenic and teratogenic effects of the humic acids were found, HA and its sodium salt were allowed for oral treatment of all food animals for prevention and therapy of diarrhoeal diseases and intoxications (EMEA 1999).

Colloidal characteristics of HA and their salts and their ability to form chelates, they can significantly modify the toxic effects of a number of xenobiotics and undesirable substances that enter the digestive tract together with feeds and water (Livens 1991; Herzig et al. 1994). Their strong affinity to mutagens (Cozzi et al. 1993), pesticides (Negre et al. 2001; Li et al. 2003), monoaromatic and polycyclic aromatic compounds (Kollist Sügur et al. 1993; Nanny and Maza 2001), heavy metals (Livens 1991; Madroňová et al. 2001; Hammock et al. 2003; Herzig et al. 2007), aflatoxin B (Van Rensburg et al. 2006) and microorganisms (Fein et al. 1999) was described. Positive effects of oxihumolite resulting in a decreased ammonia concentration in the stable environment of market broilers and pigs were obtained by Suchý et al. (1999) and Herzig et al. (2001). Reduced emissions of ammonium from the environment of market pigs were also obtained by Ji et al. (2006) after supplementation of the diet with humic compounds.

Lead belongs to heavy metal group characterised by high accumulation in the organs and tissues of the animals and people exposed through inhalation or orally. The bone tissue is a depot tissue where up to $90 \%$ of the total organism lead accumulates. Due to its toxic effect on the central and peripheral nervous systems, damage of tubular cells in kidneys, immune system and carcinogenesis lead is investigated at present and its occurrence in the environment is monitored (Flegal and Smith 1995; Lee et al. 2001; Lurie et al. 2006), even though the lead levels in the investigated human population groups in industrial countries have a decreasing trend (Černá et al. 2001).

The purpose of the present experiment was to investigate a short-term humic acid feeding of the lead-treated pullets on its concentration in the organs, muscles and selected parameters of metabolism.

\section{Materials and Methods}

Forty hybrid 9-week-old ISA BROWN chickens (pullets) with live weight of $892 \pm 67.8 \mathrm{~g}$ were used. The experiment was performed under good hygienic conditions in the accredited animal facilities at the Veterinary Research Institute in Brno (experiment authorization No. 930/07), according to the law and approved by an ethical committee. Chickens were housed on grids in boxes equipped with feeders and drinkers. The diet and drinking water were available ad libitum. During the experiment, the chickens were kept under the regime of $12 \mathrm{~h}$ light $-12 \mathrm{~h}$ dark cycles. The conditions of animal hygiene were monitored by continuous measurements of ambient temperature and relative humidity. After the adaptation period, the chickens were allocated to 4 groups with 10 birds in each according to the following schedule:

Negative control group $(\mathrm{K})$ - chickens were fed the diet without supplements.

Positive control group (HA) - chickens were fed the diet and $0.5 \mathrm{~g}$ humic acid/chicken/day.

Experimental group $(\mathrm{Pb})$ - chickens were fed the diet and treated with $1.42 \mathrm{mg} \mathrm{Pb}\left(3.54 \mathrm{mg} \mathrm{CH}_{3} \mathrm{COO}\right)_{2}$ $\left.\mathrm{Pb} .4 \mathrm{H}_{2} \mathrm{O}\right) /$ chicken/day.

Experimental group $(\mathrm{Pb}+\mathrm{HA})$ - chickens were fed the diet and treated with $1.42 \mathrm{mg} \mathrm{Pb} /$ chicken/day and concurrently $0.5 \mathrm{~g} \mathrm{HA} /$ chicken/day.

The feed mixture K2 ISA with $88.6 \%$ of dry matter contained the following essential nutrients $(\mathrm{g} / \mathrm{kg}): 198.6$ nitrogenous substances, 3.74 fat, 25.2 crude fibre and 46.8 ashes. The capsules containing lead acetate or HA were wetted with oil and administered on the tongue root every morning for 10 days. The feed consumption by respective chicken groups was registered during the whole experimental period and the health status was monitored every day.

The chickens were weighed at the beginning and the end of the trial, always at the same time and the same sequence of groups. Before euthanasia by narcotic overdose (xylasine and ketamine), blood samples were collected by puncture of vena basilica for analysis of selected biochemical indicators. After euthanasia, liver and 
kidney were weighed and the samples of livers, kidneys, leg bones (femur) and muscles (m. biceps femoris) were collected. The samples were stored at $-18{ }^{\circ} \mathrm{C}$ before analysis.

Humic acid (batch No. B03A1) was prepared at the Research Institute of Inorganic Chemistry (Ústí nad Labem, Czech Republic). The analysed sample contained (\%): 90.63 dry matter, 86.89 humic acid and 3.74 ashes. HA was prepared by sedimentation and centrifugation of potassium humate with sulphuric acid at $\mathrm{pH} 1.5-1.7$ and dried at room temperature. The sample analysis of lead content showed $3.52 \mathrm{mg} / \mathrm{kg} \mathrm{Pb}$.

The lead content was assessed in samples of feeding mixture, HA, livers, kidneys, bones and muscles. The weight of the samples was as follows: liver 5-10 g; kidney, bone and feeding mixture 2-5 g of each and HA 0.5-1 g. Lead was assessed after a dry decomposition $\left(450 \pm 20^{\circ} \mathrm{C}\right)$ in the AAnalyst- 800 apparatus (Perkin Elmer) at the temperature of atomization $1800^{\circ} \mathrm{C}$ and the wavelength of $283.3 \mathrm{~nm}$. The detection limit was $0.02 \mathrm{mg} /$ $\mathrm{kg}$. Validity of the analysis was checked by the use of certified reference material Bovine Liver $\left(\mathrm{BCR}^{\circledR}-185 \mathrm{R}\right.$, Belgium). The presented values are arithmetic means of samples measured in duplicates.

The contents of dry matter, nitrogenous substances $(\mathrm{N} \times 6.25)$, fat, crude fibre and ashes in the diet were assessed (AOAC 2001).

Total protein (TP), albumin (Alb), glucose (Glu), triacylglycerols (TG), cholesterol (Chol), uric acid (UC), alkaline phosphatase (ALP), aspartate and alanine aminotransferases (AST, ALT), calcium (Ca), phosphorus (P), magnesium $(\mathrm{Mg})$, iron $(\mathrm{Fe})$ and copper $(\mathrm{Cu})$ blood plasma concentrations were determined spectrophotometrically using Bio-La-Tests (PLIVA - Lachema Brno, Ltd., Czech Republic).

All values were presented as means \pm SD. Significance of the between-group differences in mean values was assessed by the one-way analysis of variance (ANOVA) followed by Tukey test, or by the non-parametric KruskalWallis test. The statistical analysis was performed with the STAT Plus software (VRI, Brno, Czech Republic).

\section{Results and Discussion}

Analysis of the complete feeding mixture for the contents of chemical elements showed the following concentrations (mg/kg): $\mathrm{Cu}$ 15.2, $\mathrm{Zn} \mathrm{61.8,} \mathrm{Se} \mathrm{0.215} \mathrm{and} \mathrm{Fe} \mathrm{102.0,} \mathrm{which}$ complied with the requirements for the used category of chickens. Of toxic elements (heavy metals), $0.0002 \mathrm{mg} \mathrm{Hg}, 0.02 \mathrm{mg} \mathrm{Cd}$ and $0.1 \mathrm{mg} \mathrm{Pb} / \mathrm{kg}$ in the diet were detected. The lead content was 100-fold lower than is the highest admissible amount for feeding raw materials (Anonymous 2004). The low Pb levels confirmed the references concerning the decreasing values since early 1980s from both objective reasons (decreased environmental pollution and exposure doses) and methodical reasons - less exact methods and potential contamination of samples (Černá et al. 2001).

Table $1 . \mathrm{Pb}$ levels in chicken kidneys, liver, leg muscle and bone $(\mathrm{mg} / \mathrm{kg}, \mathrm{n}=10)$

\begin{tabular}{|l|c|c|c|c|}
\hline Parameters & $\mathrm{K}$ & $\mathrm{HA}$ & $\mathrm{Pb}$ & $\mathrm{Pb}+\mathrm{HA}$ \\
\hline Liver & & & & \\
\hline $\mathrm{x}$ & $<0.02^{\mathrm{A}}$ & $<0.02^{\mathrm{A}}$ & $0.1^{\mathrm{B}}$ & $0.07^{\mathrm{C}}$ \\
\hline $\mathrm{SD}$ & 0 & 0 & 0.025 & 0.024 \\
\hline Kidneys & & & & \\
\hline $\mathrm{x}$ & $0.063^{\mathrm{A}}$ & $0.028^{\mathrm{A}}$ & $0.781^{\mathrm{B}}$ & $0.439^{\mathrm{C}}$ \\
\hline $\mathrm{SD}$ & 0.042 & $0.012^{2}$ & 0.099 & 0.074 \\
\hline Muscle & & & & \\
\hline $\mathrm{X}$ & $<0.01^{\mathrm{b}}$ & $<0.01^{\mathrm{b}}$ & $0.024^{\mathrm{a}}$ & $<0.01^{\mathrm{b}}$ \\
\hline SD & 0 & 0 & 0.017 & 0 \\
\hline Bone & & & & \\
\hline $\mathrm{X}$ & $0.055^{\mathrm{A}}$ & $0.088^{\mathrm{A}}$ & $2.711^{\mathrm{B}}$ & $1.338^{\mathrm{C}}$ \\
\hline SD & 0.014 & 0.016 & 0.587 & 0.205 \\
\hline
\end{tabular}

A, B, C significant differences $(P<0.001)$

${ }^{\mathrm{a}, \mathrm{b}}$ significant differences $(P<0.05)$
The mean lead levels in liver, kidneys, meat and bones of chickens from negative control group (K) constituted the background level, which reflected the current status of nutrition (Table 1). MRL (minimal residual level) for liver and kidney is $0.5 \mathrm{mg}$ and for meat $0.1 \mathrm{mg}$ $\mathrm{Pb} / \mathrm{kg}$ of fresh sample (Anonymous 2001). The detected concentrations in this case were: in liver $4 \%$, in kidneys $12.6 \%$ and in muscles $10 \%$ of allowed MRL. The highest concentrations were detected in kidneys and bones $(0.063$ \pm 0.042 and $0.055 \pm 0.014 \mathrm{mg} / \mathrm{kg}$, respectively). The significantly higher lead accumulation in parenchymatous organs was confirmed by various authors. In wild animals, Kramárová et al. (2005) detected the highest $\mathrm{Pb}$ concentrations in kidneys $(0.115$ to $0.780 \mathrm{mg} / \mathrm{kg})$ and in livers $(0.177$ to $1.904 \mathrm{mg} / \mathrm{kg})$. The detection of the low $\mathrm{Pb}$ content in muscles in our experiment is in accordance with the findings reported by Vos et al. (1990) and Tahvonen and Kumpulainen (1994). Gonzales Weller et al. (2006) found the mean concentration of $0.0069 \mathrm{mg} / \mathrm{kg}$ in chicken and the turkey meat; these values were below detection limit. 
Differences in the mean lead content between parenchymatous organs and muscles of the humic acid treated chickens (group HA) were comparable with chickens of group K; lead concentration in bones $(0.088 \pm 0.016 \mathrm{mg} / \mathrm{kg})$ was non-significantly higher. It does not seem probable that the increased bone depot resulted from the $\mathrm{Pb}$ content in humic acid $(3.52 \mathrm{mg} / \mathrm{kg})$.

Our results showed that the 10-day oral administration of lead at a dose higher (by about $50 \%$ ) than allowed by our limits for the feeds (Anonymous 2004) caused a significant increase in the lead content in the liver, kidneys and bones $(P<0.001)$ and in muscles $(P$ $<0.05)$ of experimental chickens $(\mathrm{Pb})$ in comparison with controls (Table 1). The limits established by the European Commission (Anonymous 2001) were exceeded in kidneys $(0.781 \pm 0.099 \mathrm{mg} / \mathrm{kg})$. Nearly a 50 -fold increase in lead levels in bones $(2.711 \pm 0.587 \mathrm{mg} /$ $\mathrm{kg}$ ) gave evidence of the target tissue that is an objective indicator of the degree of exposure of an organism to environmental stress providing information of its total accumulation rate (Hamilton and O'Flaherty 1994).

During concurrent administration of humic acid and lead acetate (groups $\mathrm{Pb}+\mathrm{HA}$ ), a significant decrease in $\mathrm{Pb}$ concentration was detected in all investigated organs and tissues, i.e. in the liver, kidneys, muscles and bones by $30 \%, 43.8 \%, 58.3 \%$ and $50.6 \%$, respectively, in comparison with chickens treated only with $\mathrm{Pb}$. The beneficial effect of humic acid is in accordance with the results of Herzig et al. (2007) who tested the effects of HA on cadmium retention in chicken broilers. As shown in our study, humic acids due to their structure and numerous function groups can absorb metal cations that become less toxic, their absorption is difficult or their transport activities in organism may be decreased (Livens 1991; Klocking 2002; Hammock et al. 2003). Reduced availability of sodium humate from gastrointestinal tract was documented by Hampl et al. (1994) who failed to find a significant decrease of cadmium in chicken liver and kidneys when the oral administration of sodium humate was delayed after cadmium administration.

Table 2. Selected biochemical characteristics of blood sera of chickens $(x \pm S D ; n=10)$

\begin{tabular}{|l|c|c|c|c|c|}
\hline Indicators & & $\mathrm{K}$ & $\mathrm{HA}$ & $\mathrm{Pb}$ & $\mathrm{Pb}+\mathrm{HA}$ \\
\hline Total protein & $\mathrm{g} / 1$ & $39.05 \pm 3.88$ & $37.88 \pm 1.77$ & $36.13 \pm 8.77$ & $33.26 \pm 6.78$ \\
\hline Albumin & $\mathrm{g} / \mathrm{l}$ & $14 \pm 1.09$ & $13.8 \pm 0.75$ & $12.4 \pm 2.84$ & $11.6 \pm 2.5$ \\
\hline ALT & $\mu \mathrm{kat} / \mathrm{l}$ & $0.058 \pm 0.004$ & $0.062 \pm 0.01$ & $0.065 \pm 0.02$ & $0.061 \pm 0.03$ \\
\hline $\mathrm{ALP}$ & $\mu \mathrm{kat} / 1$ & $23.4 \pm 7.17$ & $17.62 \pm 4.84$ & $17.32 \pm 7.19$ & $13.36 \pm 2.87$ \\
\hline AST & $\mu \mathrm{kat} / 1$ & $3.51 \pm 0.11$ & $3.6 \pm 0.21$ & $3.19 \pm 0.84$ & $2.94 \pm 0.63$ \\
\hline Uric acid & $\mu \mathrm{mol} / 1$ & $118.67 \pm 54.33$ & $117.1 \pm 27.18$ & $152.9 \pm 76.6$ & $146.8 \pm 67.66$ \\
\hline Cholesterol & $\mathrm{mmol} / 1$ & $2.78 \pm 0.34$ & $2.77 \pm 0.3$ & $2.5 \pm 0.59$ & $2.36 \pm 0.69$ \\
\hline Triacylglycerol & $\mathrm{mmol} / 1$ & $0.355 \pm 0.03$ & $0.405 \pm 0.08$ & $0.38 \pm 0.22$ & $0.65 \pm 0.1$ \\
\hline Glucose & $\mathrm{mmol} / 1$ & $12.13 \pm 0.6$ & $12.13 \pm 0.6$ & $10.99 \pm 2.19$ & $10.27 \pm 1.73$ \\
\hline Iron & $\mathrm{mmol} / 1$ & $17.75 \pm 1.55$ & $17.15 \pm 3.01$ & $14.53 \pm 3.75$ & $14.93 \pm 3.93$ \\
\hline Calcium & $\mathrm{mmol} / 1$ & $2.78 \pm 0.15$ & $2.77 \pm 0.17$ & $2.56 \pm 0.51$ & $2.33 \pm 0.36$ \\
\hline Phosphorus & $\mathrm{mmol} / 1$ & $2.17 \pm 0.1$ & $2.18 \pm 0.11$ & $1.95 \pm 0.39$ & $1.9 \pm 0.27$ \\
\hline Magnesium & $\mathrm{mmol} / 1$ & $0.832 \pm 0.03$ & $0.792 \pm 0.06$ & $0.728 \pm 0.15$ & $0.674 \pm 0.13$ \\
\hline Cuprum & $\mathrm{mmol} / 1$ & $2.73 \pm 0.95^{\mathrm{A}}$ & $2.83 \pm 0.21^{\mathrm{a}}$ & $2.0 \pm 0.53$ & $1.42 \pm 0.45^{\mathrm{Bb}}$ \\
\hline
\end{tabular}

A, B significant differences $(P<0.01)$

${ }^{\mathrm{a}, \mathrm{b}}$ significant differences $(P<0.05)$

Evaluation of the effect of humic acid, lead and their concurrent feeding on the efficiency and health of the chickens was included in the relatively short-term study. The growth activity depression was notable in the lead-treated group; the live body weight gain was lower by 22.2 to $29.7 \%$ in comparison with both control groups (Table 2). Strong inhibition 
of growth in rats was observed by Hamilton and O'Flaherty (1994). The positive effect of humic acid is evident by obtaining the highest mean live body weight gain (231.0 \pm $23.5 \mathrm{~g})$ in group $\mathrm{HA}$ or in group $\mathrm{Pb}+\mathrm{HA}(200.2 \pm 33.3 \mathrm{~g})$. The feed conversion was also most favourable in group HA; it is in accordance with the results of humic acid testing in broilers (Kocabagli et al. 2002). No significant differences between groups were detected for liver and kidney weight. Grosicki and Kowalski (2002) obtained comparable results after heavy metal treatment of rats for 28 days.

During the experiment, no clinical symptoms of disease were observed in the groups exposed to lead. Lower concentration of copper was detected in the blood serum of the $\mathrm{Pb}+\mathrm{HA}$ group in comparison with group $\mathrm{K}$ and HA $(P<0.01, P<0.05)$. Decreased concentrations of cooper could be caused by formation of metal-humic complexes. Besides heavy metals, $\mathrm{Zn}, \mathrm{Cu}, \mathrm{Mn}, \mathrm{Au}, \mathrm{Fe}, \mathrm{Al}$ and Se can also form these complexes as reported by Livens (1991). The other biochemical indicators ranged within physiological limits (Meluzzi et al. 1992); no significant differences were found between the mean values of different groups of animals; that is in accordance with the results obtained after chicken treatment with humic substances (Demeterová and Mariščáková 2006).

\section{Vliv kyseliny huminové na ukládání olova v orgánech a svalovině kuřat}

Cílem práce bylo zjistit vliv perorální aplikace huminové kyseliny (HA) při 10 denní zátěži kuřic olovem na jeho koncentrace $\mathrm{v}$ orgánech a svalovině. Do pokusu bylo zařazeno 40 kuřic rozdělených do čtyř skupin po deseti kusech. Kontrolní skupina (K) přijímala bazální dietu bez suplementace. Druhá skupina (HA) byla krmena bazální dietou s HA $\mathrm{v}$ dávce $500 \mathrm{mg}$ per chicken/day. První pokusná $(\mathrm{Pb})$ príijímala s bazální dietou octan olovnatý v dávce $3.54 \mathrm{mg}(1.42 \mathrm{mg} \mathrm{Pb})$ na kus /den a druhá pokusná skupina $(\mathrm{Pb}+\mathrm{HA})$ navíc denně prijímala $500 \mathrm{mg}$ HA. Ve vzorcích jater, ledvin, kosti a svalové tkáni byl stanoven obsah olova. Velmi nízké koncentrace olova v játrech, ledvině a svalovině kontrolní skupiny představují pozadí, které je obrazem současné výživy. V uvedených tkáních koncentrace činily pouze $4 \%, 12.6 \%$ a $10 \%$ nejvyššího přípustného množství $(0,5$ a $0,1 \mathrm{mg} \mathrm{Pb} /$ $\mathrm{kg})$. V pokusné skupině kuřat $(\mathrm{Pb})$ byly zjištěny vysoce průkazně zvýšené $(P<0.001)$ koncentrace olova $v$ játrech, ledvině, kosti a ve svalovině $(P<0.05)$. Nejvyšší kumulace byla zjištěna v kosti $(2.711 \pm 0.59 \mathrm{mg} / \mathrm{kg})$. Současná aplikace HA a octanu olovnatého (HA + Pb skupina) snížila signifikantně obsah $\mathrm{Pb}$ v játrech o $30 \%$, ledvině o $43.8 \%$, svalovině o $53.8 \%$ a v kosti o 50.6 \% ve srovnání s pokusnou skupinou Pb. Hodnoty vybraných biochemických ukazatelů byly v referenčním rozmezí, vyjma průkazného snížení koncentrací mědi u pokusných skupin.

\section{Acknowledgements}

Supported by the Ministry of the Industry and Trade of the Czech Republic (Grant No. FT-TA/038) and the Ministry of Agriculture of the Czech Republic (Grant No. MZe 0002716201). The authors wish to thank Ing. A. Šimáková, A.E. from National Reference Laboratory for chemical elements SVU Olomouc, Czech Republic for assessment of lead levels.

\section{References}

ALVAREZ-PUEBLA RA GOULET PJG, GARRIDO JJ 2005: Characterization of the porous structure of different humic fractions. Colloids Surf A Physicochem Eng Asp 256: 129-135

ANONYMOUS 2001: Commission Directive (EC) 466/2001. 8.3.2001. Brussels

ANONYMOUS 2004: Notice No. 184/2004, Annex 3, Ministry of Agriculture of the Czech Republic (in Czech): 2599-2600

AOAC - Association of Official Analytical Chemists International 2001: Official Methods of Analalysis. $17^{\text {th }}$ ed. AOAC Inc., Arlington, USA

CABANERO AI, MADRID Y, CAMARA C. 2005: Effect of animal feed enriched with Se and clays on Hg bioaccumulation in chickens: In vivo experimental study. J Agric Food Chem 53: 2125-2132

ČERNÁ M, SPĚVÁČKOVÁ V, BENEŠ B, CEJCHANOVÁ M, ŠMÍD J 2001: Reference values for lead and cadmium in blood of Czech population. Int J Occup Med Environ Health 14: 189-92 
COZZI R, NICOLAI M, PERTICONE P, DESALVIA R, SPUNTARELLI F 1993: Desmutagenic activity of natural humic acids - Inhibition of mitomycin-C and maleic hydrazide mutagenicity. Mutat Res 299: 37-44

DEMETEROVÁ M, MARIŠČ́́KOVÁ R 2006: The effect of probiotic and humates on some performance and metabolic variables in broiler chickens. In: Proceedings Days of Nutrition and Veterinary Dietetics VII, Kosice: 198-201 ISBN 80-8077-034-4

EMEA 1999: Committee for veterinary medical products. Humic acids and their sodium salts. Http:/www.emea. europa.eu/pdfs/vet/mrls/055499en.pdf (accessed February 1999)

FEIN JB, BOILY JF, GUCLU K, KAULBACH E 1999: Experimental study of humic acid adsorption onto bacteria and Al-oxide mineral surfaces. Chem Geol 162: 33-45

FLEGAL AR, SMITH DR 1995: Measurements of environmental lead contamination and human exposure, Rev Environ Contam Toxicol 143: 1-45

GONZALEZ-WELLER D, KARLSSON L, CABALLERO A, HERNANDEZ F, GUTIERREZ A, GONZALEZIGLESIAS T, MARINO M, HARDISSON A 2006: Lead and cadmium in meat and meat products consumed by the population in Tenerife Island, Spain. Food Addit Contam 23: 757-763

GRIBAN VG, STEPCHENKO LM, ZHORINA LV 1988: The live weight gain and disease resistence of young cattle and poultry stock as influenced by physiologicaly active peat preparation. In: Proc VIII Intern Peat Congress, Leningrad: $45-50$

GROSICKI A, KOWALSKI B 2002: Lead, cadmium and mercury influence on selenium fate in rats. Bull Vet Inst Pulawy 46: 337-343

HAMILTON JD, OFLAHERTY EJ 1994: Effects of lead-exposure on skeletal development in rats. Fundam Appl Toxicol 22: 594-604

HAMMOCK D, HUANG CC, MORT G, SWINEHART JH 2003: The effect of humic acid on the uptake of mercury(II), cadmium(II), and zinc(II) by Chinook salmon (Oncorhynchus tshawytscha) eggs. Arch Environ Contam Toxicol 44: 83-88

HAMPL J, HERZIG I, VLČEK J 1994: Pharmacokinetics of sodium humate in chickens. Vet Med 39: 305-313

HERZIG I, HAMPL J, DOČEKALOVÁ H, PÍSAŘÍKOVÁ B, VLČEK J 1994: The effect of sodium humate on cadmium deposition in the chicken organs (in Czech). Vet Med 39: 175-185

HERZIG I, KOZLER J, PÍSAŘÍKOVÁ B, FENGL M, JURSA V 2001: Effects of a humine acid-based sorbent on the concentration of ammonia in broiler houses. Archiv Geflug 65: 246-250

HERZIG I, NAVRÁTILOVÁ M, SUCHÝ P, VEČEREK V, TOTUŠEK J 2007: Model trial investigating retention in selected tissues using broiler chicken fed cadmium and humic acid. Vet Med 52: 162-168

JI F, MCGLONE JJ, KIM SW 2006: Effects of dietary humic substances on pig growth performance, carcass characteristics, and ammonia emission. J Anim Sci 84: 2482-2490

KLOCKING R 1994: Humic substances as potential therapeutic. In: Senesi, N, Miano, TM: Humic substances in the global enviromnent and implication for human health. Elsevier Science B. V., Amsterdam: 1368 p. ISBN $0-444-89593-0$

KLOCKING R, HELBIG B, SCHÖTZ G, SCHACKE M, WUTZLER P 2002: Anti-HSV-1 activity of synthetic humic acid-like polymers derived from p-diphenolic starting compounds. Antivir Chem Chemother 13: 241-249

KOCABAGLI N, ALP M, ACAR N, KAHRAMAN R 2002: The effects of dietary humate supplementation on broiler growth and carcass yield. Poult Sci 81: 227-230

KOLLIST-SIIGUR K, NIELSEN T, GRON C, HANSEN PE, HELWEG C, JONASSEN KE, JORGENSEN O, KIRSO U 2001: Sorption of polycyclic aromatic compounds to humic and fulvic acid HPLC column materials. J Environ Qual 30: 526-537

KRAMÁROVÁ M, MASSANYI P, SLÁMECKÁ J, TATARUCH F, JANČOVÁ A, GAŠPARIK J, FABIS M, KOVÁČIK J, TOMAN R, GALOVÁ J, JURČ́́K R 2005: Distribution of cadmium and lead in liver and kidney of some wild animals in Slovakia. J Environ Sci Health A Tox Hazard Subst Environ Eng 40: 593- 600

KRUGOV VP, MAYKOVA EF 1988: Peat-based growth promoters and their use in crop and livestock production. In: Proc. VIII. Intern. Peat Congress, Leningrad: 40-44

LEE JE, CHEN SP, GOLEMBOSKI KA, PARSONS PJ, DIETERT RR 2001: Developmental windows of differential lead-induced immunotoxicity in chickens. Toxicology 156: 161-170

LENK T, BENDA A 1989: Peat paste - humic acid containing animal health agent for prophylaxis and treatment of calves for diarrhea. (In German). Monatsh Veterinarmed 44: 563-565

LI H, SHENG GY, TEPPEN BJ, JOHNSTON CT, BOYD SA 2003: Sorption and desorption of pesticides by clay minerals and humic acid-clay complexes. Soil Sci Soc Am J 67: 122-131

LIVENS FR 1991: Chemical-reactions of metals with humic material. Environ Pollut 70: 183-208

LURIE DI, BROOKS DM, GRAY LC 2006: The effect of lead on the avian auditory brainstem. Neurotoxicology 27: $108-117$

MACCARTHY P 2001: The principles of humic substances. Soil Sci 166: 738-751

MADRONOVÁ L, KOZLER J, CEZIKOVÁ J, NOVÁK J, JÁNOŠ P 2001: Humic acids from coal of the NorthBohemia coal field. III. Metal-binding properties of humic acids - measurements in a column arrangement. React Funct Polym 47: 119-123

MELUZZI A, PRIMICERI G, GIORDANI R, FABRIS G 1992: Determination of blood-constituents reference values in broilers. Poult Sci 71: 337-345 
NANNY MA, MAZA JP 2001: Noncovalent interactions between monoaromatic compounds and dissolved humic acids: A. deuterium NMR T-1 relaxation study. Environ Sci Technol 35: 379-384

NEGRE M, SCHULTEN HR, GENNARI M, VINDROLA D 2001: Interaction of imidazolinone herbicides with soil humic acids. J Environ Sci Health B 36: 107-125

RIO-SEGADE S, BENDICHO C 1998: Ultrasound-assisted extraction for mercury speciation by the flow injection cold vapor technique. J Anal Atom Spectr 14: 263-268

SUCHÝ P, HERZIG I, PÍSAŘIKOVÁ B 1999: The use of sorbents on the basis of humic acids to reduce ammonia levels in stable environment. Vet Med 44: 331-338

TAHVONEN R, KUMPULAINEN J 1994: Lead and cadmium contents in pork, beef and chicken, and in pig and cow liver in Finland during 1991. Food Addit Contam 11: 415-426

VAN RENSBURG CJ, VAN RENSBURG CEJ, VAN RYSSEN JBJ, CASEY NH, ROTTINGHAUS GE 2006: In vitro and in vivo assessment of humic acid as an aflatoxin binder in broiler chickens. Poult Sci 85: 1576-1583

VOS G, LAMMERS H, KAN CA 1990: Cadmium and lead in muscle-tissue and organs of broilers, turkeys and spent hens and in mechanically deboned poultry meat. Food Addit Contam 7: 83-91 
